\title{
Cloning, isolation, and characterization of novel chitinase-producing bacterial strain UM01 (Myxococcus fulvus)
}

\author{
Umar Shahbaz and Xiaobin Yu*
}

\begin{abstract}
Background: Chitin is an important biopolymer next to cellulose, extracted in the present study. The exoskeleton of marine bycatch brachyuran crabs, namely Calappa lophos, Dromia dehaani, Dorippe facchino and also from stomatopod Squilla spp. were used to extract chitin through fermentation methods by employing two bacterial strains such as Pseudomonas aeruginosa, Serratia marcescens. The yield of chitin was $44.24 \%, 37.45 \%, 11.56 \%$ and 27.24\% in C. lophos, D. dehaani, D. facchino and Squilla spp. respectively. FT-IR spectra of the produced chitin exhibit peaks which is more or less coherent to that of standard chitin which is further analysed by Scanning Electron Microscope. The quality of produced chitin was assessed through moisture, protein, ash and lipid content analysis ensured that chitin obtained from trash crustaceans are on par with that of standard chitin.

Results: A total of 10 samples were collected from different areas of Jiangsu China for screening of chitinaseproducing bacteria. Based on the clearance zone, two of the best samples were chosen for further study. 16S rRNA sequence analysis showed that this strain belongs to genus Myxococcus and species Myxococcus fulvus.

Phylogenetic analysis was performed and it shows strain UM01 is a novel bacterial strain. UM01 isolate shows maximum chitinase production at $35^{\circ} \mathrm{C}$ and $8 \mathrm{pH}$. Among all, these colloidal chitins were found to be the best for chitinase production. Three chitinase-producing genes were identified and sequenced by using degenerative plasmid. UMCda gene (chitin disaccharide deacetylase) was cloned into E. coli DH5a by using PET-28a vector, and antagonistic activity was examined against $T$. reesei.

Conclusion: To our knowledge, this is the earliest study report to gene cloning and identification of the chitinase gene in Myxococcus fulvus. Chitinase plays a key role in decomposition and utilization of chitin as a raw material. This research indicates that Myxococcus fulvus UM01 strain is a novel myxobacteria strain and can produce large amounts of chitinase within a short time. The UMCda gene cloned into E. coli DH5a showed a promising effect as antifungal activity. In overall findings, the specific strain UM01 has endowed properties of bioconversation of waste chitin and other biological applications.
\end{abstract}

Keywords: Myxococcus fulvus, Gene cloning, Chitinase

\section{Background}

Chitin is the second most abundant natural biopolymer after cellulose. The chemical structure of chitin is similar to that of cellulose with 2-acetamido2-deoxy-b-D-glucose

\footnotetext{
* Correspondence: xybu@jiangnan.edu.cn

The Key Laboratory of Carbohydrate Chemistry \& Biotechnology, Ministry of Education, School of Biotechnology, Jiangnan University, 1800 Lihu Road, Wuxi 214122, China
}

\section{Springer Open}

(c) The Author(s). 2020 Open Access This article is licensed under a Creative Commons Attribution 4.0 International License, which permits use, sharing, adaptation, distribution and reproduction in any medium or format, as long as you give appropriate credit to the original author(s) and the source, provide a link to the Creative Commons licence, and indicate if changes were made. The images or other third party material in this article are included in the article's Creative Commons licence, unless indicated otherwise in a credit line to the material. If material is not included in the article's Creative Commons licence and your intended use is not permitted by statutory regulation or exceeds the permitted use, you will need to obtain permission directly from the copyright holder. To view a copy of this licence, visit http://creativecommons.org/licenses/by/4.0/. the chitin word derived from the Greek "chiton" which means coat of mail [1]. In 1828, French botanist Henri Braconnot noticed that polysaccharide took title chitin as he researched edible mushrooms [2]. Chitin $\left(\mathrm{C}_{8} \mathrm{H}_{13} \mathrm{O}_{5} \mathrm{~N}\right)_{\mathrm{n}}$ is related to a cellulose that is a long 2acetamido-2-deoxy- $\beta$-D-glucose (NAG) monomer; the units are linked via $\beta(1 \rightarrow 4)$. Chitin is semitransparent, 
and it is found in the exoskeleton of crabs, lobsters, and insects, the cell walls of fungi, the radula of mollusks, and also in the internal structures of invertebrates. Chitin serves several purposes such as strengthening the internal and external structures. Chitin is the second most common natural polysaccharide ( $\beta-(1-4)-\mathrm{N}$-acetyl-D-glucosamine), with cellulose being the first in the polymer world [3]. Chitin found in $\alpha$-chitin and $\beta$-chitin can be characterized by infrared and in solid-state NMR, together with X-ray diffraction [4]. The third allomorph form, $\gamma$-chitin, was characterized with different chemical properties [5], but detailed investigations show that it is just a variant of $\alpha$-chitin [6].

Throughout years of research on this polymer, different methods have been developed for extraction. Most of the methods discussed in this literature are chemical methods used for the production of industrial chitin. The USA, Japan, Canada, China, Russia, Norway, and India largely reject the use of crustacean fishing for production [7]. Chitin extraction using strong acids and bases triggers serious consequences to process, such as low level of purity, generation of chemical effluents, and increased cost of production [8, 9]. The high quality of the final product, with affordable COP biological processes, is more attractive to various industries $[10,11]$. The main industrial sources for biopolymer extraction are byproducts of the fishing industry, such as prawns, crabs, and lobster shells $[12,13]$.

Annual production of chitin and its derivatives from living oceanic organisms are estimated at $10^{12}-10^{14}$ tons [14]. The cost of chitin is estimated at $\$ 220 / \mathrm{kg}$ on the world market [15]. In order to utilize the excess quantity of chitin, developing commercial procedures for extraction of competent polymer are needed and may reduce the harmful impacts it has on the environment, biodiversity, and human health. Chitin and its deacetylated form chitosan each are valuable economic commodities due to their elasticity of biological properties, such as crystallinity and strict insolubility. Chitin and its derivatives COS, chitosan, and glucosamine augments increase their application in the food, textile, medical, agriculture, and cosmetic industries. Chitinase bacteria are capable for hydrolyzing insoluble chitin to its oligo component and are found in various organism including bacteria, virus, fungi, insect, plant, and animal and play different physiological roles. Chitinase is an essential part of numerous bacterial species; they are well known specifically in the genera Aeromonas, Serratia, Vibrio, Bacillus, Streptomyces, and Myxobacteria. Our study aimed to report on screening, gene cloning, and antagonistic and biochemical representation of the novel strain UM01 from Myxococcus fulvus. Remarkably, the enzyme was discovered and is suitable against antifungal activity. To the best of our knowledge, this is the first research on chitinase from M. fulvus.

\section{Method}

Collection of samples and chitinolytic bacteria isolation

A total of 10 samples were collected from different areas of Jiangsu China. Four soil samples were collected form Lihu Lake (Wuxi) and Xihu Lake (Hangzhou), and the remaining 6 samples were collected from maize rhizophore and the fish market. For screening purposes, agar media containing colloidal chitin and colonies with a clear zone were used and considered for further study for chitinase, as these colonies specify chitinaseproducing bacteria.

\section{Colloidal chitin preparation}

For colloidal chitin, preparation powder chitin (case no.1398-61-4) was purchased from Sigma-Aldrich and prepared by slight modification in Hsu and with the Lockwood method [16]. Ten grams of powdered chitin was prepared by dissolving $300 \mathrm{~mL}$ conc. HCL gradually, acid was added to chitin with stirring, and mixture was allowed to stand at room temperature with alternating stirring until the chitin dissolved $(2 \mathrm{~h})$. By using 8 layers of cheesecloth (to remove large chitin chunks), the chitin-HCL solution was poured into a $2-1$ ice-cold $\left(4^{\circ} \mathrm{C}\right)$ $\mathrm{D}_{2} \mathrm{H}_{2} \mathrm{O}$ beaker and kept in the fridge overnight at $\left(4^{\circ} \mathrm{C}\right)$. After $24 \mathrm{~h}$, there will be white cake-like chitin in the solution. Next, we have to centrifuge the white cake-like chitin solution at $18,000 \mathrm{rpm}$ (F0485 Fix-Angle-Rotor) for $15 \mathrm{~min}$. We then proceeded to wash it with $\mathrm{D}_{2} \mathrm{H}_{2} \mathrm{O}$, at least 4 times until pH 5 is reached. Lastly, we loosened the colloidal by using $100 \mathrm{~mL}$ distill water to make w/w solution and stored it at $4{ }^{\circ} \mathrm{C}$ with an aluminum covering.

\section{Culture media preparation}

For identification of bacteria, LB (Luria broth) is the most commonly used medium; for screening chitinaseproducing bacteria, selective medium is used. Selective medium containing $\left(\mathrm{g} \mathrm{L}^{-1}\right) \mathrm{KH}_{2} \mathrm{PO}_{4}, 14 ; \mathrm{K}_{2} \mathrm{HPO}_{4}, 6$; $\left(\mathrm{NH}_{4}\right)_{2} \mathrm{SO}_{4}, 2 ; \mathrm{Na}_{3} \mathrm{C}_{6} \mathrm{H}_{5} \mathrm{O}_{7}, 1 ; \mathrm{MgSO}_{4}, 0.12$; Agar, 15; with $1 \%(\mathrm{w} / \mathrm{v})$ colloidal chitin at $\mathrm{pH} 7$, were incubated at 30 to $37^{\circ} \mathrm{C}$. The clearance zone was formed by chitin hydrolysis and was recorded up to 8 days. Based on the size of clearance zone, two of the best samples were chosen for further study.

\section{Gram staining procedure}

The standard gram staining procedure was performed for the characterization of isolate [17].

\section{Biochemical tests}

Different chemical tests were performed to test the motility and oxidase. The nitrate reduction test and urease test were used for characterization [18]. 


\section{Enzyme assay}

Colloidal chitin was used as the substrate for measuring the chitinase activity according to originally modified protocol [19]. Reaction mixture consists of $0.5 \mathrm{~mL}$ enzyme which was added to $0.5 \mathrm{~mL}$ colloidal chitin $(1 \% \mathrm{w} /$ v); it was then incubated at $45^{\circ} \mathrm{C}$ for $1 \mathrm{~h}$. The reaction was terminated at $90^{\circ} \mathrm{C}$ for $5 \mathrm{~min}$ after incubation. The reaction mixture was then centrifuged at 20,000 $g$ (F0485 Fix-Angle-Rotor) for $5 \mathrm{~min}$, and the supernatant was collected. The supernatant was boiled with $0.8 \mathrm{M}$ potassium tetraborate of $100 \mu \mathrm{L}$ quantity and boiled for $3 \mathrm{~min}$, followed by the addition of $1 \mathrm{~mL}$ of dimethylamino benzaldehyde for $30 \mathrm{~min}$ at room temperature, and then incubated until it appeared to be a pink color. Absorbance was measured at $560 \mathrm{~nm}$ by using a spectrophotometer. A blank solution was used as a negative control. One chitinase enzyme unit was defined as a change in the absorbance of $0.01 \mathrm{~min}^{-1}$ [20].

\section{Molecular characterization of microorganism DNA sequencing}

The gene coding 16S rRNA was sequenced to identify the genus of each strain. The genomic DNA of the selected strains were isolated by using the TIANamp Bacterial DNA kit, and amplification was performed by using the PCR master mix kit with initial heating step for $2 \mathrm{~min}$ at $95^{\circ} \mathrm{C}$ followed by denaturation step $30 \mathrm{cy}$ cles of $95^{\circ} \mathrm{C}$ for $30 \mathrm{~s}$, annealing for $60 \mathrm{~s}$ at $55^{\circ} \mathrm{C}$, and 2 min extension at $72^{\circ} \mathrm{C}$, and then followed by final extension at $72{ }^{\circ} \mathrm{C}$ for $7 \mathrm{~min}$. Two universal primers FC 27 (forward) and RC1429 (reverse) were used for amplification. The amplified product was than purified by using DNA purification kit, the purified product was sent to Sangon Biotech Shanghai for sequencing, and 16S rRNA sequence was obtained. 16S rRNA sequence analysis showed that this strain belongs to genus Myxococcus and species Myxococcus fulvus.

\section{Phylogenetic analysis}

The gene coding 16S rRNA partial sequence obtained from Sangon Biotech Shanghai (www.sangon.com) was compared to other bacterial sequences to search for their pairwise identities by using NCBI, BLAST (BLAST; http://www.ncbi.nlm.nih.gov/BLAST/), and online software. Multiples sequence alignments of highly similarity sequences were available at the data bank and were performed by using MEGAX (Version 10.1.5). By using the neighbor-joining method (NJ), phylogenetic analysis was carried out with the MEGAX (Version 10.1.5) [21]. Partial gene coding $16 \mathrm{~S}$ rRNA sequence was then submitted to NCBI Gene bank with the name UM01 under the accession number MN811202.1 [22].

\section{Determination of different substrates and effect on} enzyme production

To determine the best substrate for chitinase production, various substrates such as (1\%) colloidal chitin, powdery chitin, crab shell, and chitosan were used. Final $20 \mathrm{mg} / \mathrm{mL}$ substrate concentration was used in the final reaction mixture and the increase reductively was determined [23].

\section{Effect of temperature and $\mathrm{pH}$ on enzyme production}

The effect of temperature for optimum enzyme production was determined at 20 to $55^{\circ} \mathrm{C}$ by using colloidal chitin as a substrate, and the $\mathrm{pH}$ value effect on enzyme production was examined by varying $\mathrm{pHs}$ from $\mathrm{pH} 3.5$ to pH 9 in culture medium at optimized temperatures and incubation period. Tris-HCL buffer ( $\mathrm{pH} 6.5$ to 9) and acetate buffer ( $\mathrm{pH} 3.5$ to 6.0 ) were used for this purpose.

\section{Chitinase gene amplification}

Five starter primers were used for amplification of chitinase gene from UM01 strain:

BBGA (F): ATGAGCACAAATAACATTATTAAT GC, BBGA (R): TTAGGCGATGAGCTGCC

BBGB (F): ATGCAGCTTCCAGGATTCC, BBGB (R): TTACGGGTAGGTGTCCAGGT

BBGC (F): ATGCAGAGGTCCCTCGC, BBGC (R): TTAGCGCACG AACTCCC

BBGD (F): ATGTCTGGCAATTTTGTTTCAC, BBGD (R): TTAGCAGCCCAGGTTGC

BBGE (F): ATGGCCATGGCCGTG, BBGE (R): TTAGGGCTGGAAGGCTTCC

All these primers were designed by searching the database $(\mathrm{NCBI})$ to find the closest relative sequence. By putting all these sequences in FASTA format in a text document, we were able to do multiple alignments using Clustal Omega. For amplification of the chitinase gene, genomic DNA from strain UM01 was used by using TIANamp bacterial DNA kit and amplification was performed by using PCR master mix kit by following standard PCR protocol. The obtained PCR product was analyzed by gel electrophoresis and an amplified purified product was sent to Sangon Biotech Shanghai for sequencing.

\section{Cloning of (UMCda) chitinase gene}

The coding region of the chitinase gene (UMCda) was amplified by PCR with the flanking restriction enzyme by using forward primer BBG71F: CCGGAATTCA TGAACAAAACTTCCCGTAC and reverse primer BBG7R: CCCAAGCTTTTATTTGCTCAGGTTGA CGT, and PCR products were purified by using PCR purification kit (Thermo fisher). By using the restriction enzyme EcoR1 and HIND111, the PCR product were digested and then ligated into pET-28 plasmid vector, 
which was digested with the same restriction enzyme. By using the heat shock method, the recombinant vector transformed into E. coli $D H 5 a$. The recombinant $E$. coli $D H 5$ a strain was grown in LB medium containing 100 $\mathrm{mg} / \mathrm{mL}$ kanamycin at $37^{\circ} \mathrm{C}$ in a rotatory shaker 180 rpm. When the optical density $(\mathrm{OD}=600)$ of culture media has reached up to 0.5 , expression of recombinant protein was induced by IPTG $0.5 \mathrm{mM}$ and culture was grown at $37^{\circ} \mathrm{C}$ at $12 \mathrm{~h}$.

\section{Purification of recombinant chitinase and chitinase assay}

The reaction mixture containing $0.1 \mathrm{~mL}$ enzyme solution and $0.1 \mathrm{~mL}(1 \%)$ colloidal chitin which was incubated at $45^{\circ} \mathrm{C}$ for $30 \mathrm{~min}$, and the reducing sugar was determined [23]. The one unit of enzyme activity is defined $1 \mu \mathrm{mol}$ of GlcNAc obtained from enzyme hydrolysis during 1 min using $1 \mathrm{~mL}$ of enzyme.

For purification of recombinant chitinase, $1 \mathrm{~mL}$ of overnight culture was induced with IPTG; the cell was then harvested by using centrifugation at $4{ }^{\circ} \mathrm{C}$ at $10,000 \mathrm{rpm}$ and re-suspended again in $1 \mathrm{~mL}$ PBS buffer then centrifuged again $12,000 \mathrm{rpm}$ for $1 \mathrm{~min}$, followed by a second wash with $55 \mu \mathrm{L}$ PBS buffer. The cell was disrupted by using sonication and again centrifuged at $4{ }^{\circ} \mathrm{C}$ at $10,000 \mathrm{rpm}$ for $30 \mathrm{~min}$ to obtain suspension. Purification of the enzyme was done by using NI-NTA affinity chromatography and imidazole used as an eluent. Column chromatography purified chitinase enzyme was loaded to DEAEcellulose A52 $(2.6 \times 20 \mathrm{~cm})$ column. A different salinity of tris $0.05 \mathrm{M} \mathrm{HCL}$ and $\mathrm{pH} 7$ was applied. Elution step was preceded in a stepwise gradient of $\mathrm{NaCl}(0-1.0 \%)$ at the flow rate of $0.5 \mathrm{~mL} / \mathrm{min}$. The selected fraction was applied for Sephadex G-100 column $(1.6 \times 30)$. Purified column was eluted with tris $0.05 \mathrm{M} \mathrm{HCL}$ and at $\mathrm{pH} 7$ with the rate of 0.4 $\mathrm{mL} / \mathrm{min}$. The fraction of each $3 \mathrm{~mL}$ was collected and chitinase activity with protein content of each fraction was determined accordingly [24]. The purified beak was chosen for determining the properties of chitinase enzyme. SDS-PAGE using $12 \%$ gel in Tris-glycine buffer $\mathrm{pH} 8.3$ [25] was done to determine enzyme homogeneity. Chitinase activity was measured by using a modified method [26].

\section{Antifungal activity of chitinase gene}

To evaluate the antifungal activity of the recombinant chitinase gene, it was measured against Trichoderma reesei IFO 31329 using a chitinase plate assay by using a slightly modified method of the previous study [27]. Recombinant strain was streaked at the center of the agar plates containing 1:1 (v/v) ratio of potato dextrose agar (PDA) and yeast extract mannitol) (YEM) with the addition of $0.5 \%$ colloidal chitin and was incubated at
Table 1 Classification and morphological properties of Myxococcus fulvus UM01 strain

\begin{tabular}{ll}
\hline Morphological characteristics & \\
\hline Gram staining & Negative \\
Form & Rod \\
Motility & Positive \\
Spore & Positive \\
Habitat & Soil \\
Carbon source & Macromolecules \\
Oxygen requirement & Aerobic \\
Pathogenicity & Non-pathogen \\
Biosafety level & 1 \\
Geographical location & China \\
Classification & \\
Phylum & Proteobacteria \\
Class & Deltaproteobacteria \\
Order & Myxococcales \\
Family & Myxococcaceae \\
Genus & Myxococcus \\
Species & Myxococcus fulvus \\
Strain & UM01 \\
\hline
\end{tabular}

100-3000 bp Ladder-K

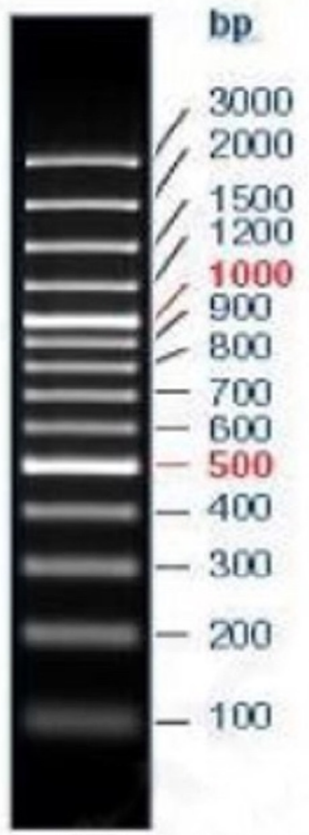

1. 78 Aearose

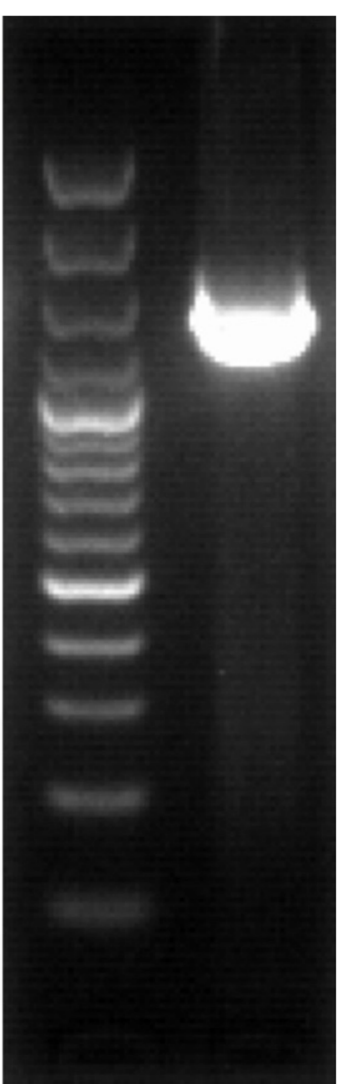

Fig. 1 Gene 165 rRNA of M. fulvus UM01 strain 


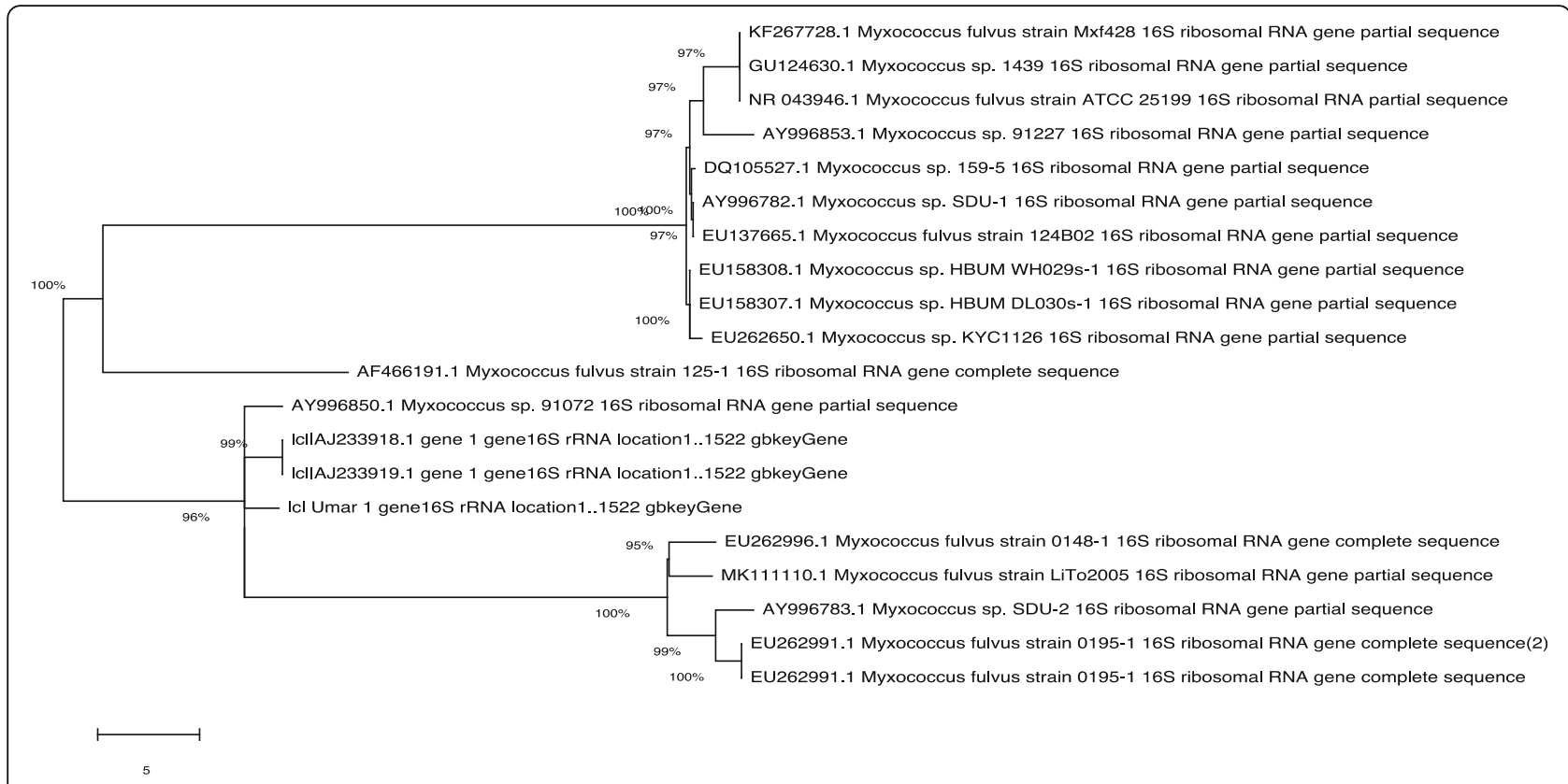

Fig. 2 Phylogenetic analysis of M. fulvus UM01 strain mentioned in this tree with the name ICI Umar 1 gene $16 \mathrm{~S}$ rRNA showing its similarity with AY996850.1 Myxococcus sp. 91072

$37^{\circ} \mathrm{C}$ for $24 \mathrm{~h}$ for bacterial growth. Next, we inoculated each bacterial (recombinant) colony and the mentioned strain in a straight line. After a 24-h incubation period at $37^{\circ} \mathrm{C}$, a mycelial lump of $T$. reesei was placed on the center of the plate. One plate with bacterial inoculation was used as a control. Both plates were incubated at $37^{\circ} \mathrm{C}$ for 3 days, and the antifungal activity of recombinant was evaluated by visual examination.

\section{Results}

A total of two chitinolytic bacteria were identified by screening the 10 soil samples that were collected from different regions in China. Based on colloidal degradation and the clear zone, two colonies were identified as the best; both of them were used for secondary screening by using broth media and enzyme assays. Based on the chitinase production, one isolate was used for further study.

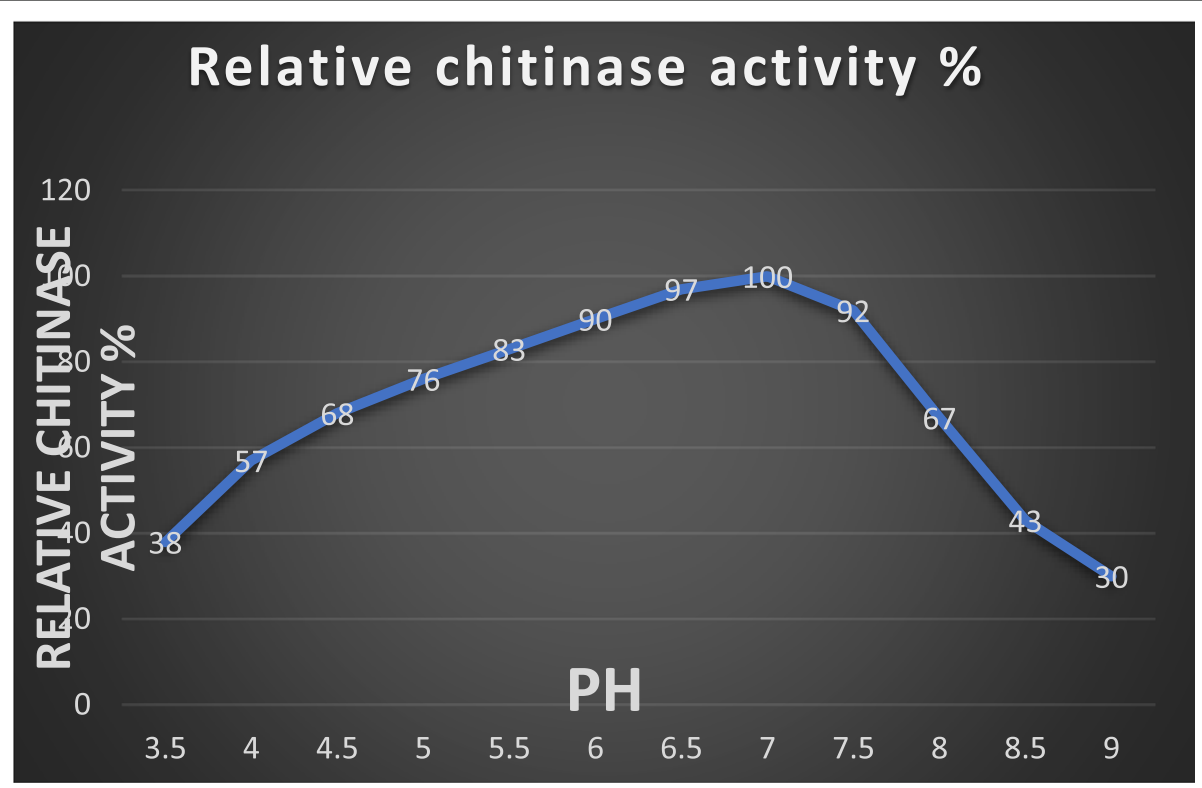

Fig. 3 Effect of pH on chitinase production by UM01 


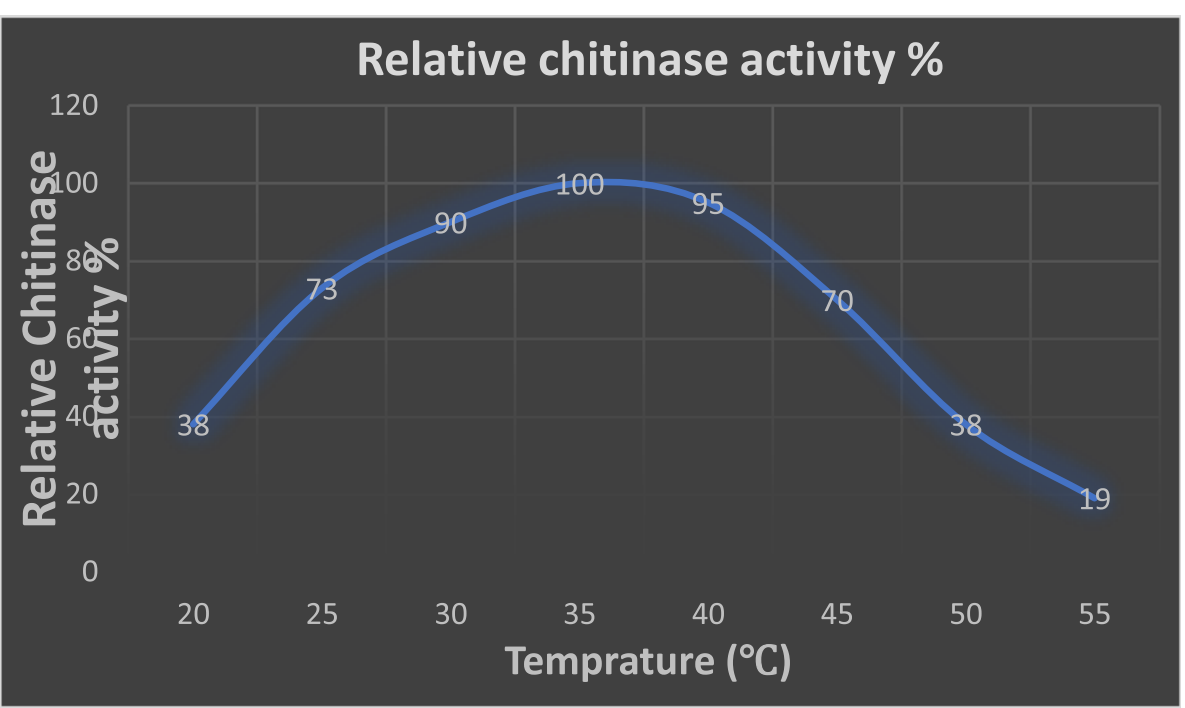

Fig. 4 Effect of temperature on chitinase production by UM01

\section{Identification and molecular phylogeny of bacteria}

Identification of the novel isolated bacteria strain UM01 was done by both the catabolic and molecular methods. The strain identified as $M$. fulvus is a typical species of the genus Myxococcus in the family Myxococcaceae. Colonies on the agar plate were raised, were smooth, and were a light-yellow color which turned light pink with time. Classification and morphological properties of strain UM01 are shown in (Table 1).

\section{Gene coding $16 \mathrm{~S}$ rRNA analysis}

A 1476 bp of $16 \mathrm{~S}$ rRNA gene was sequenced from strain UM01. Gel pictures of the amplified product shown in

Fig. 1 were submitted to NCBI under accession no.
MN811202.1. Strain UM01 shows maximum homology with strain Myxococcus fulvus strain 0195-1 and Myxococcus sp. SDU-1.

\section{Phylogenetic tree analysis}

Phylogenetic analysis was performed by using MEGAX (Version 10.1.5). Only the highest sequence of homology score was used after NCBI Blast was considered for constructed phylogenetic tree shown in Fig. 2.

\section{Effect of $\mathrm{pH}$ on chitinase production}

To evaluate enzyme activity and stability, bacteria culture was grown at different $\mathrm{pH}$ ranges such as $\mathrm{pH} 3.5$ to $\mathrm{pH}$ 9. The optimum $\mathrm{pH}$ of UM01 chitinase production

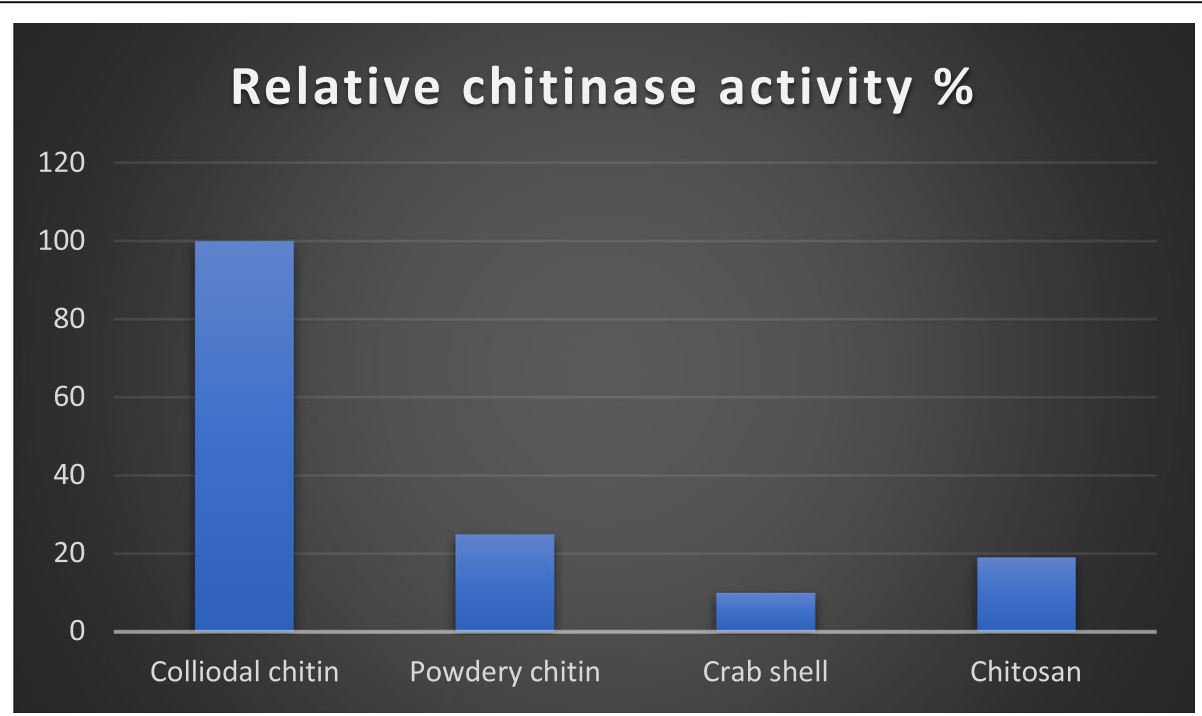

Fig. 5 Effect of different substrates on chitinase production by UM01 
was at $\mathrm{pH} 7$, and its activity was stable at $\mathrm{pH} 5.5$ to $\mathrm{pH} 8$ as shown in Fig. 3. The above results indicated that the $\mathrm{pH}$ of the media individually did not only help chitinase production but it also performed a key role in cell growth. Like Myxococcus fulvus 124B02, the study previously also reported optimum $\mathrm{pH} 6$ to $\mathrm{pH} 7.6$ for bacterial growth [18].

\section{Effect of temperature on chitinase production}

Temperature is a key factor for various biological processes for bacterial growth and enzyme production, which also is affected by a change in incubation temperature. To measure enzyme activity and stability, UM01 was grown at a different incubation temperature which ranges from 20 to $55^{\circ} \mathrm{C}$. Chitinase production was highest at $35^{\circ} \mathrm{C}$. With increased temperatures of 40 to $55^{\circ} \mathrm{C}$, the enzyme activity started decreasing as shown in Fig. 4; Myxococcus fulvus $124 B 02$ and Myxococcus fulvus KYC4048 both show optimum growth at $32^{\circ} \mathrm{C}[18,28]$.

\section{Effect of substrate on chitinase production}

To specifically measure the best substrate in chitinase production, the strain UM01 was used in different substrates such as colloidal chitin, powdery chitin, crab shell, and chitosan. Among all, these colloidal chitins were found to be the best for chitinase production, and powdery chitin and crab shell had lower activity as shown in Fig. 5. The previous study also proved that Eisenia fetida shows great chitinase activity by using colloidal chitin as a substrate [29].

\section{Sequence analysis of UM01 chitinase-producing gene}

By using the degenerative primer, 3 chitinase-coding genes were identified after PCR amplification gel electrophoresis was run to analyze these genes as shown in Fig. 6. All 3 genes were sequenced by Sangon Biotech Shanghai, for sequence analysis. Chitinase18 (glycoside hydrolase family 18 ) is $1024 \mathrm{bp}$ long. Sequence comparison was done by using the online software NCBI BLAST (http://www. ncbi.nlm.nih.gov/BLAST/) alignment with another glycoside hydrolase gene derived from Serratia Marcescens strain WVU-005, Serratia Marcescens strain UMH12, and Serratia Marcescens subsp. Marcescens Db11 obtained with the sequence identity of $94.93 \%$ and the $E$ value $=0$. UMCBP (chitin-binding protein) 592 bp long gene by sequence comparison with online tool NCBI BLAST and alignment with another CBP gene from Serratia Marcescens strain E28, Serratia Marcescens strain CAV1761, and Serratia Marcescens strain S2I7 was obtained with the sequence identity of 97.4 to $97.0 \%$ and the $E$ value $=0$. UMCda (chitin disaccharide deacetylase) $749 \mathrm{bp}$ long gene after NCBI

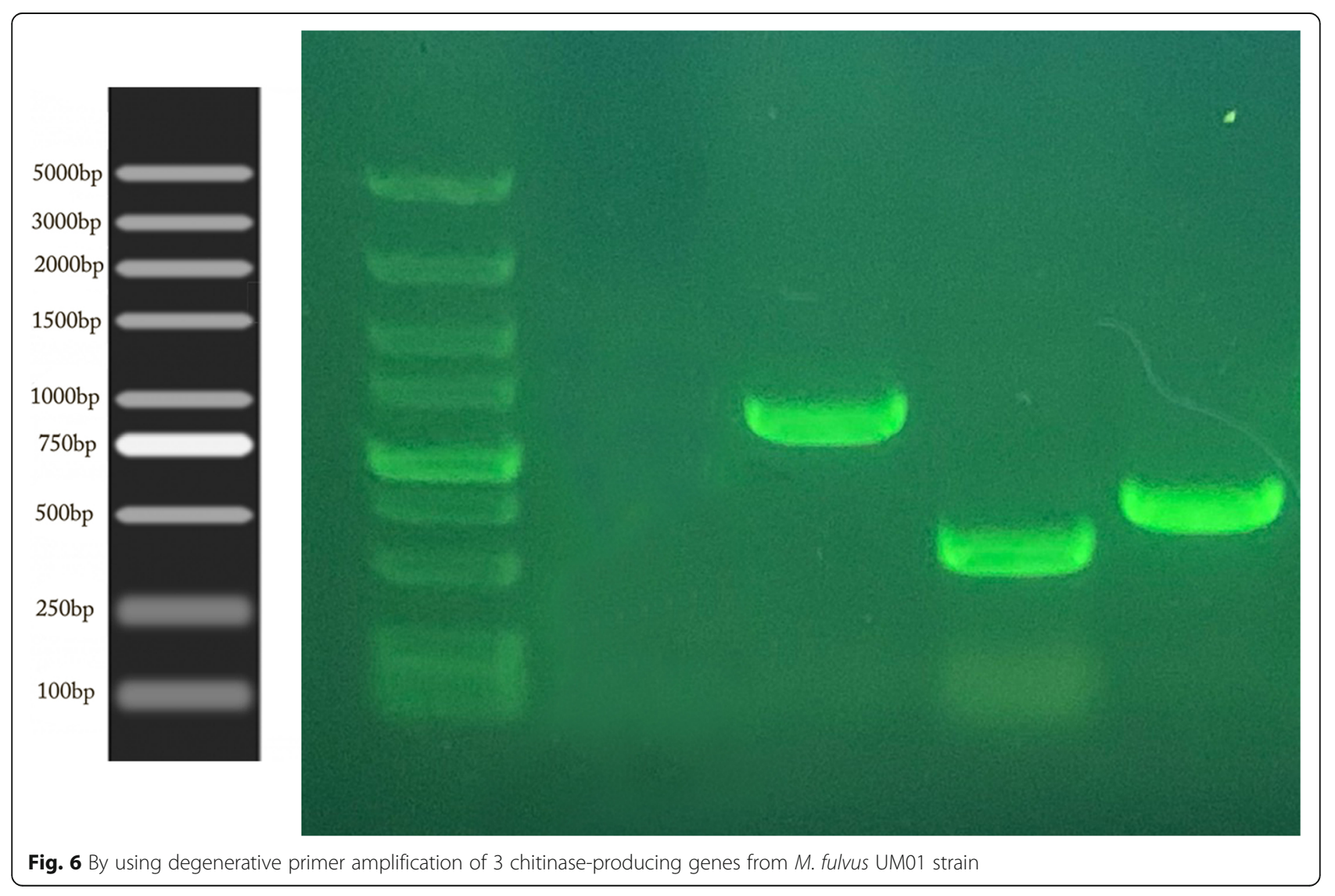


blast alignment with the other $\mathrm{Cda}$ genes derived from Serratia Marcescens isolate GN26, Serratia Marcescens SMB2099, and Serratia Marcescens strain C110 was obtained with sequence identity 95.5 to $96.3 \%$ and the $E$ value $=0$.

\section{Cloning and purification of UMCda gene}

UMCda gene CDS was submitted to Banklt under accession no. MT249254.1 [30] and was overexpressed into $E$. coli DH5a by using PET-28a vector, with and without signal peptide exhibited; there was no alternation on protein expression and enzyme activity. Gel electrophoresis analysis of pET-28a vector and UMCda gene after a restriction cut with the same enzyme is shown in Fig. 9. About $60.2 \mathrm{mg}$ of recombinant UMCda protein was obtained from $1 \mathrm{l}$ of culture by using Ni-affinity chromatography. The molecular weight of UMCda is approximately $26.99 \mathrm{kDa}$ measured by using SDS-PAGE analysis as shown in Fig. 7. For structure prediction analysis, online tool Phyre2 was used for protein 3D structure. Protein UMCda shows 100\% confidence and 98\% coverage and i.d \% 37 with fold 7-stranded beta/alpha barrel, superfamily glycoside hydrolase/deacetylase, and family YdjC-like9 (Fig. 8).

\section{Antifungal activity of UmCda gene}

The UM01 strain was further studied against the antifungal activity (Fig. 9). The selected gene UMCda was cloned, and the antifungal activity of UMCda was examined against $T$. reesei by dual-culture assay as shown in Fig. 10. The recombinant UMCda gene shows a strong antagonistic activity. Antagonistic activity was also reported by Cellulosimicrobium cellulans 191 [31] and Myxococcus sp. KYC 1136, 1126, and 2001 were tested for antifungal activity in vitro [32]. Hyphal inflation was followed by distortion [33], and cell wall secretion of the chitin oligosaccharides and cytoplasmic outflow were detected by fungi after chitinase was affected [34].

\section{Discussion}

Chitin is the second most abundant polysaccharide, after cellulose, in the marine ecosystem. Chitin naturally exists in numerous sources such as insects (ladybugs, silkworms, wax worms, and butterflies), mollusks (oyster shells and squid pens), crustaceans (shrimp, lobster, and crab), and fungi (Mucor rouxii, Aspergillus niger, Penicillium chrysogenum, and Lactarius vellereus) [35]. Myxobacteria are recognized because of their large size genome beyond $9 \mathrm{Mb}$ and their social behaviors. Myxococcus fulvus belongs to the genus Myxococcus in the Myxococcaceae family. In this study, chitinase UMCda was expressed by E. coli $\mathrm{DH} 5 \mathrm{a}$ and showed the highest activity on colloidal chitin than the other substance. Meanwhile, the main product of chitin is GlcNAc$_{2}$; other oligosaccharides are not detected, which

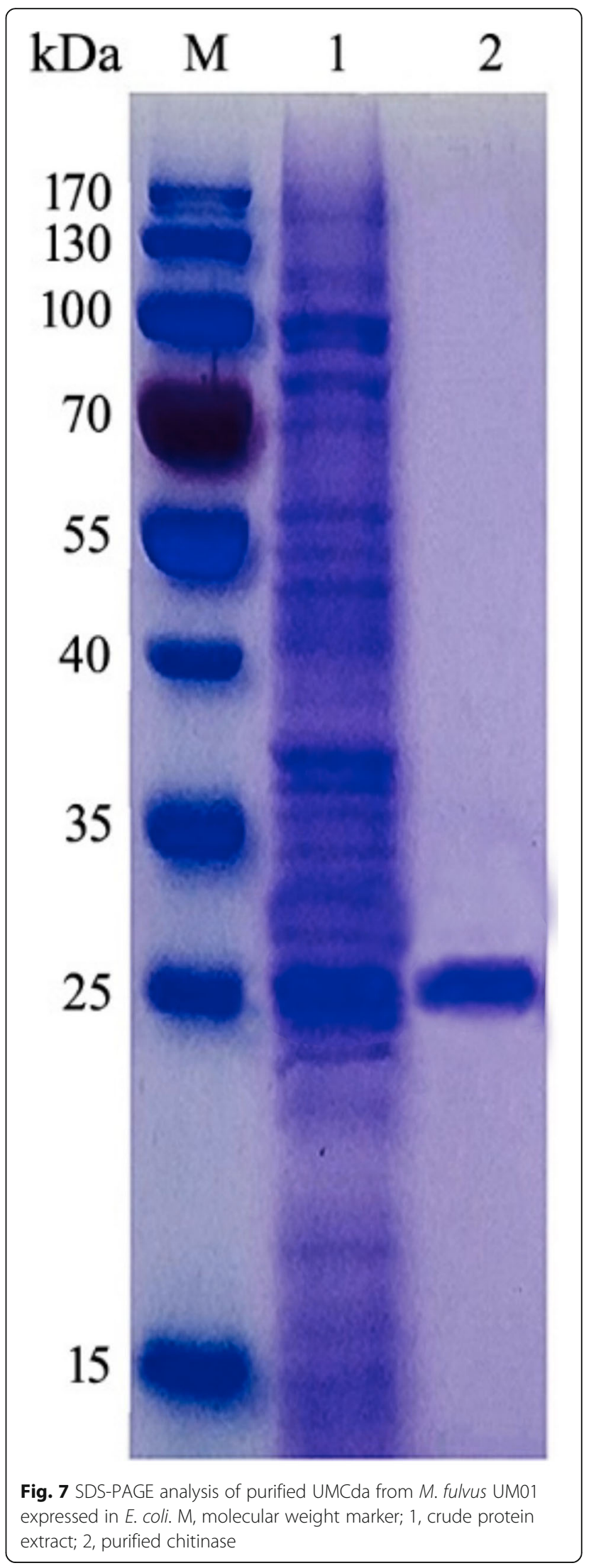




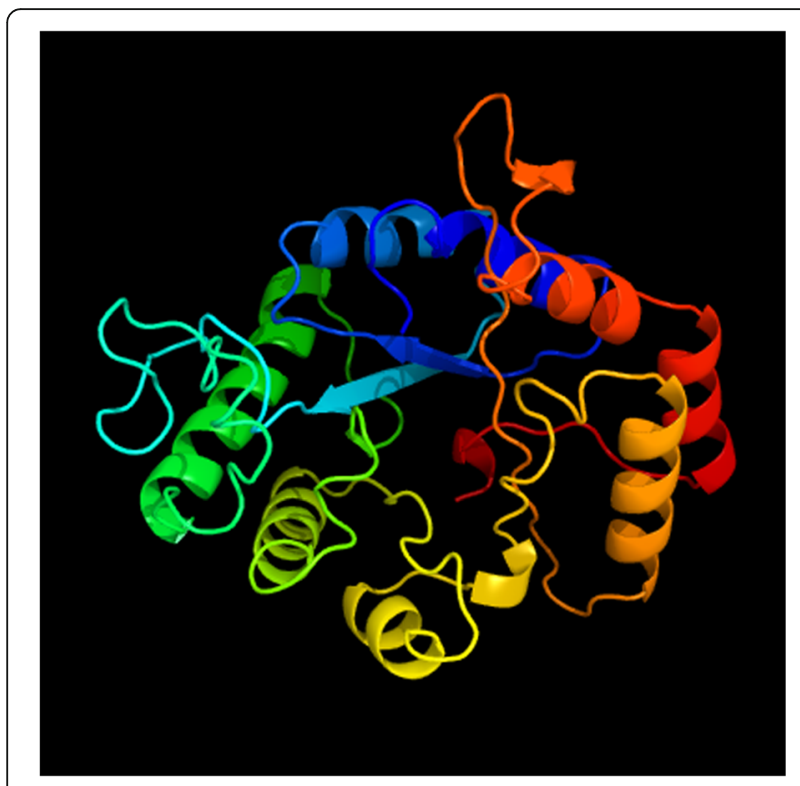

Fig. 8 3D structure prediction of UMCda protein provide convenience for the purification of product. Recently, chitin oligosaccharides gained lot of research attention worldwide because of their potential use in biomedical, agriculture, and food industries. Myxococcus species is well known due to its potential biocontrol agent and chitinase production; various reports have specified chitinase production from Myxococcus xanthus [36]. This research reports first time the chitinase gene production from Myхососcus fulvus screened from soil. Chitinase from Myxococcus fulvus exhibited maximum activity on colloidal chitin. The fact is that the individual chitinase are often different in their optimum $\mathrm{pH}$ and optimum temperature even from same species. The purified UM01 shows more optimum compared with that earlier studied from Myxococcus fulvus $32{ }^{\circ} \mathrm{C}$ [28] and from Serratia marcescens $45^{\circ} \mathrm{C}$. The optimal $\mathrm{pH}$ value of chitinase enzyme UM01 determined $\mathrm{pH} 7$ as its lower value compared with Myxococcus xanthus with $\mathrm{pH} 7.5$ [37]. Single sharp band at $26.9 \mathrm{kDa}$ was determined as the molecular weight of the one purified, which is approximately close to that of chitinase produced from Monacrosporium thaumasium (30 kDa), Bacillus cereus 108 (30 $\mathrm{kDa})$, and Bacillus licheniformis strain jS (22 kDa) [37-39]. Our study showed that Myxococcus fulvus UM01 produced

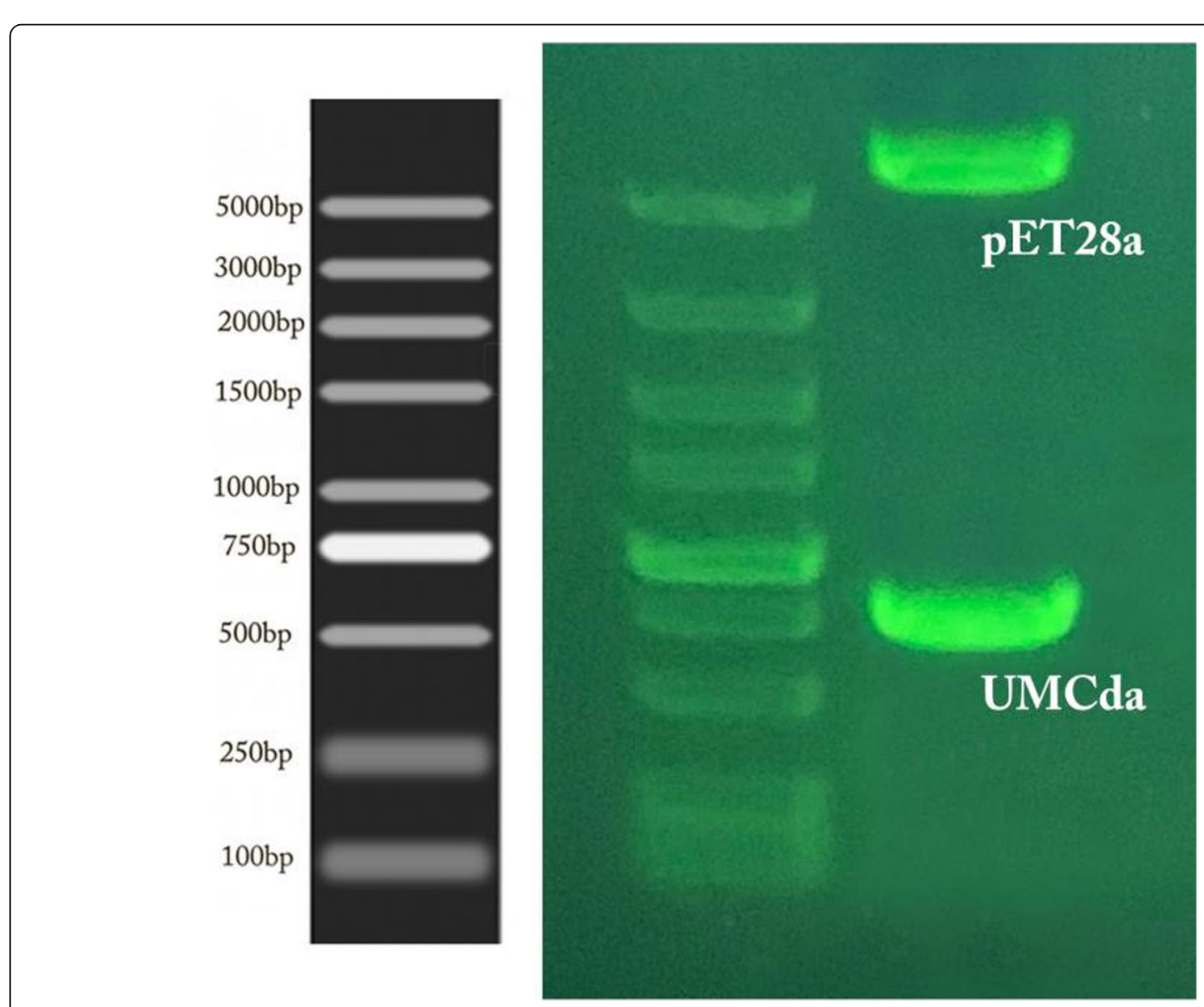

Fig. 9 Gel electrophoresis analysis of pET-28a vector and UMCda gene after successful transformation 

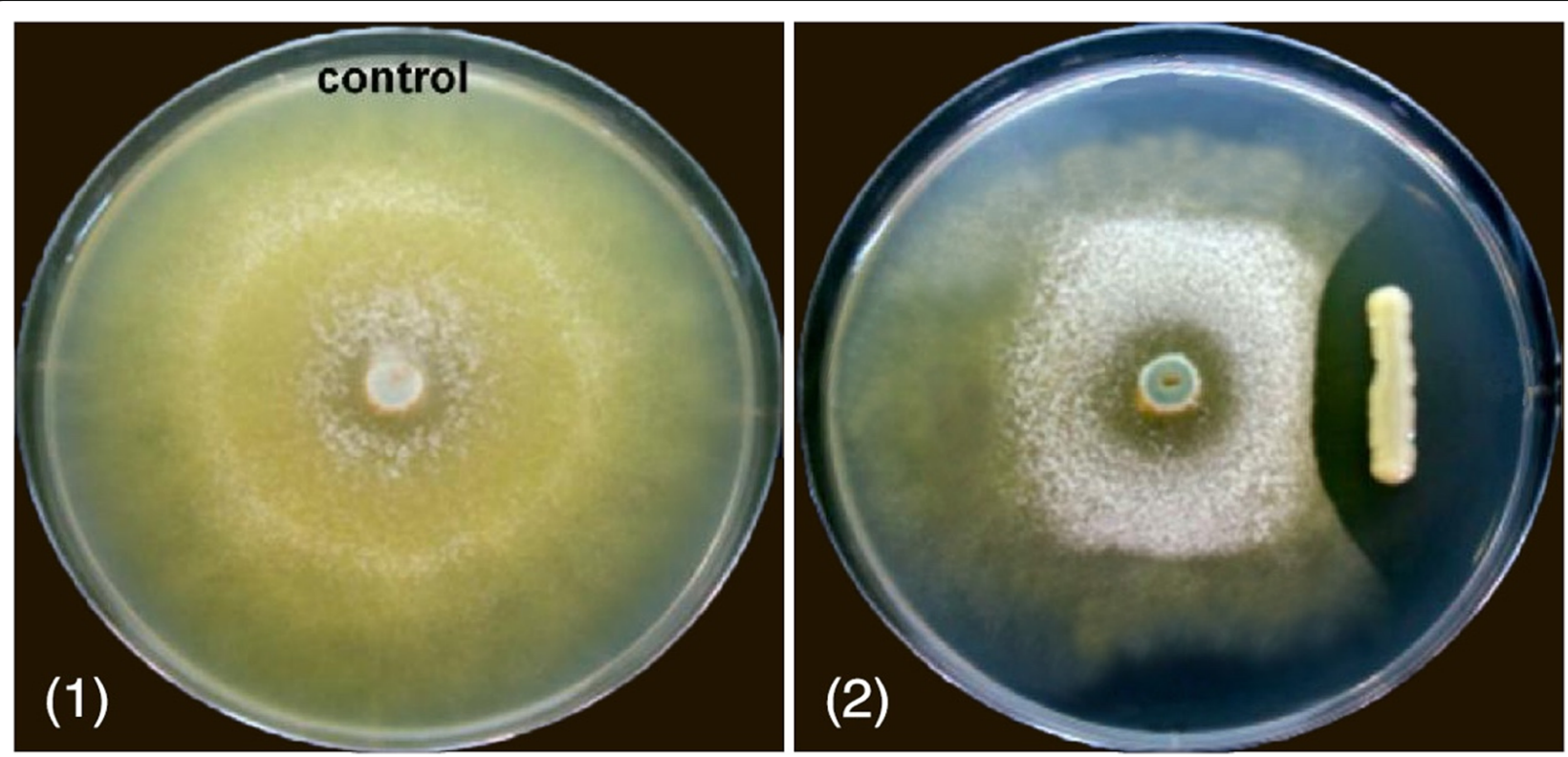

Fig. 10 Antagonistic properties of UMCda against hyphal growth of T. reesei by dual culture assay. 1 Plate used as a control. $\mathbf{2}$ Antifungal activity of UMCda

antifungal chitinase. The synthesis of chitinolytic enzyme depends on many factors, including composition of medium and the chitin source. The antifungal activity of Myxococcus fulvus UM01 was examined using its cells and crude. Although the crude proteins distinctly inhibited the hyphal growth of $T$. reesei, the cells did not suppress mycelial extension. The antifungal activity of crude proteins could be due to other components such as antifungal proteins and/or antifungal antibiotics other than chitinases that remained in the crude protein fraction after dialysis. However, such antifungal proteins and antifungal antibiotics have not been reported yet from this bacterium. In addition, our observations revealed that this isolate grew poorly and slowly on solid media such as YEM, synthetic medium, tryptone soya broth, nutrient broth, and LB. This strain exhibited better growth on media containing glucose, colloidal chitin, or glycol chitin, but the growth of the strain was still slower than that of the other isolates.

\section{Conclusion}

To our knowledge, this is the earliest study to report gene cloning and identification of the chitinase gene in Myxococcus fulvus. Chitinase plays a key role in decomposition and utilization of chitin as a raw material. This research indicates that the Myxococcus fulvus UM01 strain is a novel myxobacteria strain and can produce large amounts of chitinase within a short time. The UMCda gene cloned into E. coli DH5a showed a promising effect with antifungal activity. In overall findings, the specific strain UM01 has endowed properties of bioconversation of waste chitin and other biological applications. There is a need for further study of the enzyme action and 3D protein structure of UMCda protein. Chitin deacetylase can hydrolyze acetamide, a group of chitin, and produce chitosan which can be used for biomedical, pharmaceutical, food, and agriculture industries.

\section{Abbreviations}

COP: Cost of production; COS: Chitosan oligosaccharides; CBP: Chitin-binding protein; PCR: Polymerase chain reaction

\section{Acknowledgements}

Funding of this research is provided under CSC no: 2017GXZ017947.

\section{Authors' contributions}

US proposed the experimental work data analysis and wrote the manuscript. TCA and PK conducted the experiments. XY supervised all the experiments and with final modifications to the manuscript. The authors have read and approved the final manuscript.

\section{Funding}

Funding of this research is provided under CSC no: 2017GXZ017947.

\section{Availability of data and materials}

16S rRNA gene of strain UM01 submitted to NCBI under accession no. MN811202.1

UMCda gene CDS submitted to Banklt under accession no. MT24925.

Ethics approval and consent to participate Not applicable.

Consent for publication

Not applicable

Competing interests

The authors declare that they have no competing interests 
Received: 8 April 2020 Accepted: 5 August 2020

Published online: 31 August 2020

\section{References}

1. Aideia 3 ZE 2 EM 1; N I-D, Hoda AM. Using of chitosan as antifungal agent in Kariesh cheese. New York Sci J 2012;5(9)

2. Muzzarelli RAA, Boudrant J, Meyer D et al (2012) Current views on fungal chitin/chitosan, human chitinases, food preservation, glucans, pectins and inulin: a tribute to Henri Braconnot, precursor of the carbohydrate polymers science, on the chitin bicentennial. Carbohydr Polym 87:995-1012. https:// doi.org/10.1016/j.carbpol.2011.09.063

3. Azuma K, Ifuku S, Osaki T et al (2014) Preparation and biomedical applications of chitin and chitosan nanofibers. J Biomed Nanotechnol 10: 2891-2920. https://doi.org/10.1166/jbn.2014.1882

4. Rudall KM, Kenchington W (1973) The chitin system. Biol Rev 48:597-633. https://doi.org/10.1111/j.1469-185x.1973.tb01570.x

5. Rudall KM (2007) Chitin and its association with other molecules. J Polym Sci Part C Polym Symposia 28:83-102. https://doi.org/10.1002/polc. 5070280110

6. Atkins $E$ (1985) Conformations in polysaccharides and complex carbohydrates. J Biosci 8:375-387. https://doi.org/10.1007/bf02703990

7. Shahbaz U (2020) Chitin, characteristic, sources, and biomedical application. Curr Pharm Biotechnol 21. https://doi.org/10.2174/ 1389201021666200605104939

8. Hajji S, Younes I, Ghorbel-Bellaaj O et al (2014) Structural differences between chitin and chitosan extracted from three different marine sources. Int J Biol Macromol 65:298-306. https://doi.org/10.1016/j.ijbiomac.2014.01.045

9. Flores-Albino B, Arias L, Gómez J et al (2012) Chitin and L(+)-lactic acid production from crab (Callinectes bellicosus) wastes by fermentation of Lactobacillus sp. B2 using sugar cane molasses as carbon source. Bioprocess Biosyst Eng 35:1193-1200. https://doi.org/10.1007/s00449-012-0706-4

10. Jaganathan K, Raffi S, Soundarapandian P (2016) Extraction and characterization of chitin from marine bycatch crustaceans employing fermentation method. World J Pharm Pharmaceu Sci 5

11. Gortari MC, Hours RA (2013) Biotechnological processes for chitin recovery out of crustacean waste: a mini-review. Electron J Biotechnol 16. https://doi. org/10.2225/vol16-issue3-fulltext-10

12. Hamdi M, Hammami A, Hajji S et al (2017) Chitin extraction from blue crab (Portunus segnis) and shrimp (Penaeus kerathurus) shells using digestive alkaline proteases from P. segnis viscera. Int J Biol Macromol 101:455-463. https://doi.org/10.1016/j.ijbiomac.2017.02.103

13. Maruthiah T, Palavesam A (2017) Characterization of haloalkalophilic organic solvent tolerant protease for chitin extraction from shrimp shell waste. Int J Biol Macromol 97:552-560. https://doi.org/10.1016/j.ijbiomac.2017.01.021

14. Dhillon GS, Kaur S, Brar SK, Verma M (2012) Green synthesis approach: extraction of chitosan from fungus mycelia. Crit Rev Biotechnol 33:379-403. https://doi.org/10.3109/07388551.2012.717217

15. Jafari AM, Gharibi S, Farjadmand F, Sadighara P (2012) Extraction of shrimp waste pigments by enzymatic and alkaline treatment: evaluation by inhibition of lipid peroxidation. J Mater Cycles Waste 14:411-413. https:// doi.org/10.1007/s10163-012-0077-6

16. Hsu SC, Lockwood JL (1975) Powdered chitin agar as a selective medium for enumeration of actinomycetes in water and soil. Appl Microbiol 29:422426

17. Coico R (2005) Current protocols in microbiology. Curr Protoc Microbiol:A. 3C.1-A.3C.2. https://doi.org/10.1002/9780471729259.mca03cs00

18. Chen X-J, Han K, Feng J et al (2016) The complete genome sequence and analysis of a plasmid-bearing myxobacterial strain Myxococcus fulvus 124B02 (M 206081). Stand Genomic Sci 11:1. https://doi.org/10.1186/s40793015-0121-y

19. REISSIG JL, STORMINGER JL, LELOIR LF (1955) A modified colorimetric method for the estimation of N-acetylamino sugars. J Biol Chem 217:959966

20. Ramirez MG, Avelizapa LIR, Avelizapa NGR, Camarillo RC (2004) Colloidal chitin stained with Remazol Brilliant Blue $R^{\oplus}$, a useful substrate to select chitinolytic microorganisms and to evaluate chitinases. J Microbiol Methods 56:213-219. https://doi.org/10.1016/j.mimet.2003.10.011

21. Tamura K, Nei M, Kumar S (2004) Prospects for inferring very large phylogenies by using the neighbor-joining method. Proc National Acad Sci 101:11030-11035. https://doi.org/10.1073/pnas.0404206101
22. Shahbaz Umar, Yu X Bin (2020) Myxococcus fulvus strain UM01 165 ribosomal RNA gene, partial sequence MN811202.1. https://www.ncbi.nlm. nih.gov/nuccore/MN811202.1

23. Miller GL (1995) Use of dinitrosalicylic acid reagent for determination of reducing sugar. Anal Chem. https://doi.org/10.1021/ac60147a030

24. Jenifer DrS, J. Jeyasree, Laveena DK, KM (2014) Purification and characterization of chitinase from Trichoderma viride $n 9$ and its antifungal activity against phytopathogenic fungi. World J Pharm Pharmaceut Sci 3: 1604-1611

25. Laemmli UK (1970) Cleavage of structural proteins during the assembly of the head of bacteriophage T4. Nature 227:680-685. https://doi.org/10.1038/ $227680 \mathrm{aO}$

26. Lee Y-S, Park I-H, Yoo J-S et al (2007) Cloning, purification, and characterization of chitinase from Bacillus sp. DAU101. Bioresour Technol 98: 2734-2741. https://doi.org/10.1016/j.biortech.2006.09.048

27. Rahman MME, Hossain DM, Suzuki K et al (2016) Suppressive effects of Bacillus spp. on mycelia, apothecia and sclerotia formation of Sclerotinia sclerotiorum and potential as biological control of white mold on mustard. Australas Plant Path 45:103-117. https://doi.org/10.1007/s13313-016-0397-4

28. Lee C, Park S, Ayush I et al (2018) Effects of Myxococcus fulvus KYC4048 metabolites on breast cancer cell death. J Microbiol Biotechnol 28:765-775. https://doi.org/10.4014/jmb.1711.11003

29. Ueda M, Shioyama T, Nakadoi K et al (2017) Cloning and expression of a chitinase gene from Eisenia fetida. Int J Biol Macromol 104:1648-1655. https://doi.org/10.1016/j.ijbiomac.2017.03.140

30. Shahbaz Umar, Yu X-B (2020) Myxococcus fulvus strain UM01 chitin disaccharide deacetylase gene, partial cds. https://www.ncbi.nlm.nih.gov/ nuccore/1844545653?log\$=activity

31. Fleuri LF, Kawaguti HY, Sato HH (2009) Production, purification and application of extracellular chitinase from Cellulosimicrobium cellulans 191. Braz J Microbiol Publ Braz Soc Microbiol 40:623-630. https://doi.org/10. 1590/s1517-838220090003000026

32. Kim S-T, Yun S-C (2011) Biocontrol with Myxococcus sp. KYC 1126 against anthracnose in hot pepper. Plant Pathol J 27:156-163. https://doi.org/10. 5423/ppj.2011.27.2.156

33. Ohno A, Ano T, Shoda M (1995) Production of a lipopeptide antibiotic, surfactin, by recombinant Bacillus subtilis in solid state fermentation. Biotechnol Bioeng 47:209-214. https://doi.org/10.1002/bit.260470212

34. Vogelsang R, Barz W (1993) Purification, characterization and differential

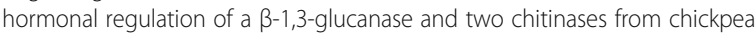
(Cicer arietinum L.). Planta 189:60-69. https://doi.org/10.1007/bf00201344

35. Yadav M, Goswami P, Paritosh K et al (2019) Seafood waste: a source for preparation of commercially employable chitin/chitosan materials. Bioresour Bioprocess 6:8. https://doi.org/10.1186/s40643-019-0243-y

36. Berleman JE, Allen S, Danielewicz MA et al (2014) The lethal cargo of Myxococcus xanthus outer membrane vesicles. Front Microbiol 5:474. https://doi.org/10.3389/fmicb.2014.00474

37. Soares FE de F, Queiroz JH de, Araújo JV de, et al (2014) Nematicidal action of chitinases produced by the fungus Monacrosporium thaumasium under laboratorial conditions. Biocontrol Sci Tech 25:337-344. doi.https://doi.org/ 10.1080/09583157.2014.979133

38. Waghmare SR, Ghosh JS (2010) Chitobiose production by using a novel thermostable chitinase from Bacillus licheniformis strain JS isolated from a mushroom bed. Carbohydr Res 345:2630-2635. https://doi.org/10.1016/j. carres.2010.09.023

39. Nguyen, Quyen HQ, Nguyen DT et al (2015) An extracellular antifungal chitinase from Lecanicillium lecanii: purification, properties, and application in biocontrol against plant pathogenic fungi [2015]. Turk J Biol 39:6-14

\section{Publisher's Note}

Springer Nature remains neutral with regard to jurisdictional claims in published maps and institutional affiliations. 